\title{
4: 74666968-74686527
}

National Cancer Institute

\section{Source}

National Cancer Institute. 4: 74666968-74686527. NCI Thesaurus. Code C41667.

Physical location of AFP_Gene 